\title{
SOSIALISASI PENCEGAHAN PENYEBARAN COVID-19 DAN PENGEMBANGAN KETAHANAN PANGAN DI KELURAHAN SABARU PALANGKARAYA
}

\author{
Yetrie Ludang $^{1}$ dan Firlianty ${ }^{2}$ \\ ${ }^{1 / 2}$ Dosen Universitas Palangka Raya Jl. Yos Sudarso, Kalimantan Tengah. Indonesia \\ Corresponding Author: Yetrie Ludang, firlianty80@gmail.com
}

\begin{abstract}
Abstrak: Sabaru merupakan salah satu kelurahan yang ada di Kecamatan Sabangau kota Palangka Raya Provinsi Kalimantan Tengah jarak lokasi dari kota palangka raya sekitar $\pm 10 \mathrm{~km}$, Pandemi covid19 yang saat ini melanda seluruh dunia mengharuskan masyarakat menjadi mandiri dalam pemenuhan gizi sebagai upaya peningkatan imunitas tubuh. Pencegahan penularan covid-19 sangat penting saat ini untuk diterapkan dalam masyarakat, karena bahaya yang diakibat virus ini sangat mengancam jiwa dan penularan yang sangat cepat. Peningkatan kesadaran masyarakat untuk pencegahan penularan covid-19 ini menjadi salah satu kegiatan pengabdian masyarakat yang dilaksanakan di kelurahan sabaru. Ketahanan pangan merupakan terjemahan dari food security mencakup banyak aspek dan luas sehingga setiap orang mencoba menterjemahkan sesuai dengan tujuan dan ketersediaan data. Permasalahan mitra adalah kurangnya kesadaran akan pentingnya pencegahan penularan covid-19 dan masyarakat juga kurang memanfaatkan lahan sekitar rumah untuk menanam sayuran yang dapat dimanfaatkan. Metode dari kegiatan ini adalah dengan cara pelatihan langsung untuk menanam sayuran disekitar tempat tinggal dan dengan penyuluhan agar menciptakan kesadaran masyarakat terhadap pentingnya pencegahan penularan covid-19. Hasil kegiatan pengabdian yang sudah dilaksanakan menunjukan adanya kesadaran dari masyarakat untuk mencegah penularan covid-19 dengan tertibnya menggunakan masker dan setiap rumah juga menyediakan tempat cuci tangan disamping rumah masing-masing, lahan pekarangan terlihat dimanfaatkan untuk bertanam sayuran.
\end{abstract}

Kata Kunci : Imunitas, Covid-19, Lahan Pekarangan

\begin{abstract}
Sabaru is one of the villages in Sabangau district, about $10 \mathrm{~km}$ from Palangka Raya, Central Kalimantan. Covid-19 pandemy that invades all over the world has made people have to work hard to fulfil their nutritional need for immunity development. Covid-19 outbreak prevention effort is very important, because the virus-induced danger highly threatens human life through fast infection. People awareness of this becomes one of the community service activities in Sabaru. Food security covers many aspects so that people try to understand it according to the goal and data availability. The problems faced are low people awareness of the covid-19 prevention and low land utilization around the house for vegetable planting. This activity included direct training of vegetable planting to develop people awareness of covid-19 infection dispersion. Results showed that local people get awareness development of the disease prevention through strict use of mask and every house has prepared hand washing facility. Besides, the house yard started bring planted with vegetable.
\end{abstract}

Keywords : Immunity, Covid-19, house yard 


\section{Pendahuluan}

\section{Analisis Situasi}

Kelurahan Sabaru secara administratif, merupakan salah satu dari 6 (enam) Kelurahan yang ada dalam Wilayah Kecamatan Sabangau, Kota Palangka Raya. Untuk mecapai Kelurahan Sabaru ini bisa ditempuh dengan jalan darat dengan jarak dari ibu kota Provinsi $\pm 10 \mathrm{~km}$.

Kelurahan Sabaru berada pada ketinggian $\pm 19 \mathrm{~m}$ di atas permukaan laut, dengan curah hujan rata-rata 1500-2000 mm/tahun, dan dengan topografi datar dan suhu udara rata-rata 27 $32^{\circ} \mathrm{C}$. Kelurahan Sabaru dihuni 4.132 jiwa dan memiliki 20,53 kepadatan penduduk per $\mathrm{km}^{2}$.

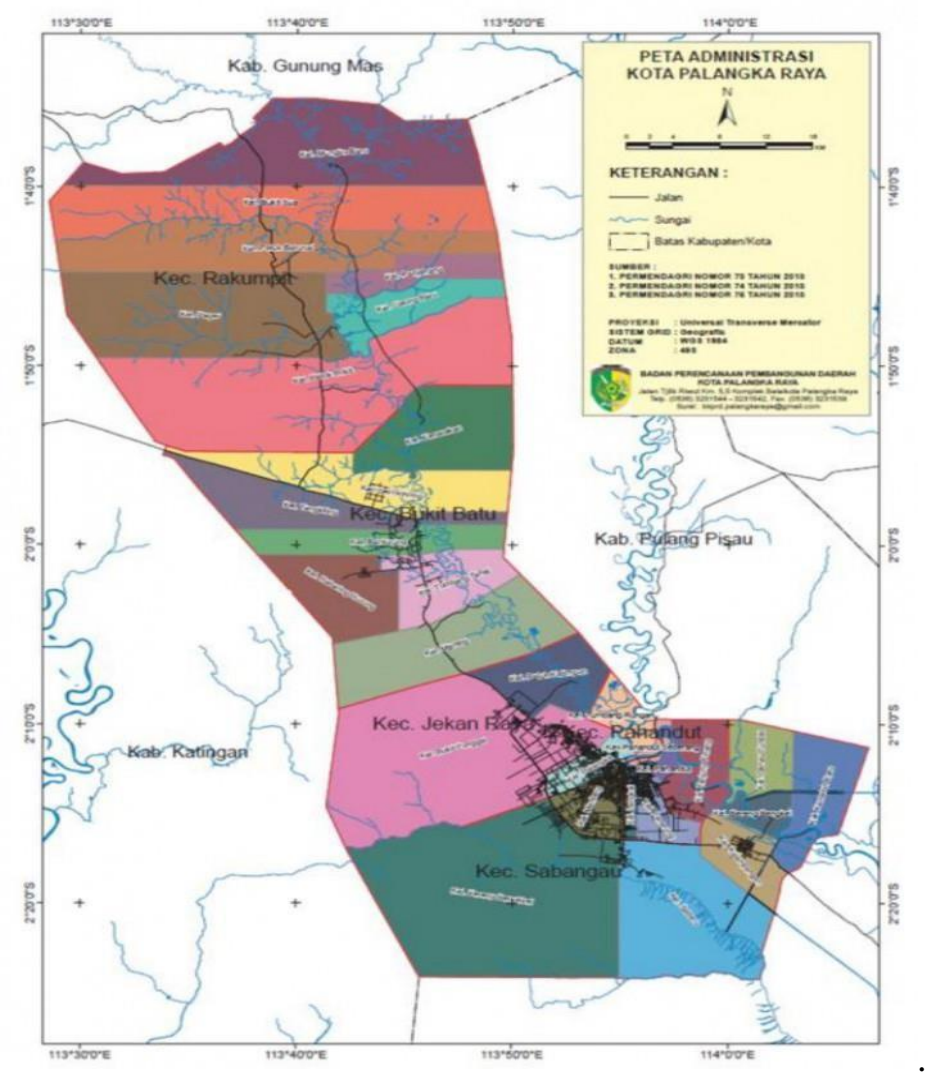

Gambar 1. Peta kota Palangka Raya

\section{Permasalahan Mitra}

Pandemic Covid-19 yang sudah berlangsung dari awal ahun 2020 dan tidak bisa diketahui kapan berakhirnya, masyarakat perlu diberikan pendampingan dalam pemahaman pentingnya kesiapan ketahanan pangan dalam menghadapi pandemic ini. Oleh karena itu perlunya dilakukan kegiatan pengabdian kepada masyarakat untuk memberikan pemahaman pentingnya ketahanan pangan keluarga di masa pandemic Covid-19 dengan memanfaatkan lahan kosong disekitar tempat tinggal. (Iseu, 2020)

Pada Kelurahan Sabaru dalam hal tata guna lahan untuk saat ini masih kearah untuk pemukiman dan pembangunan infrastuktur, dan sebagian lahan masih tergolong kosong. Pemanfaatan lahan belum secara maksimal dilakukan masyarakat dimana sebenarnya lahanlahan kosong tersebut ada yang pemilik lahan tetapi dibiarkan begitu saja dan tidak terawat, tetapi tidak sedikit juga lahan-lahan kosong tersebut digunakan untuk bercocok tanam oleh warga/pemiliknya. 
Untuk mengatasi permasalahan tersebut diperlukan adanya pelatihan/pendampingan bagi masyarakat, mengingat antusiasme warga sangat tinggi untuk mengadopsi pengetahuan tersebut, dimana kegiatan ini akan bersinergi dengan bentuk kegiatan lain yang sudah berjalan.

Tujuan kegiatan pengabdian kepada masyarakat ini untuk membantu mengatasi permasalahan yang dihadapi oleh masyarakat Pahandut seberang dengan memberikan pelatihan/pendampingan: 1). Pendampingan cara memanfaatkan lahan pekarangan sebagai lahan untuk menanam sayuran yang sangat bermanfaat bagi peningkatan gizi. 2). Peningkatan Kesadaran Masyarakat tentang pentingnya pencegahan penyebaran Covid-19 dengan melakukan kegiatan yang sesuai protocol kesehatan yang berlaku sekarang.

\section{Tujuan dan Manfaat Kegiatan}

Tujuan dari kegiatan ini adalah :

1). Pendampingan cara memanfaatkan lahan pekarangan sebagai lahan untuk menanam sayuran yang sangat bermanfaat bagi peningkatan gizi.

2). Peningkatan Kesadaran Masyarakat tentang pentingnya pencegahan penyebaran Covid-19 dengan melakukan kegiatan yang sesuai protocol kesehatan yang berlaku sekarang Manfaat dari kegiatan ini adalah memotivasi dan membuka wawasan berwirausaha untuk meningkatkan perekonomian pelaku usaha.

\section{Metodologi}

Pelaksanaan kegiatan pengabdian kepada masyarakat ini dilaksanakan bulan November 2020, pelaksanaan kegiatan ada beberapa tahapan dimulai dengan survey untuk lokasi kegiatan, pertemuan dengan apparat kelurahan dan persiapan yang dilakukan oleh tim pelaksana kegiatan dalam hal ini adalah dosen dan mahasiswa.

Tahapan untuk kegiatan pelatihan pemanfaatan pekarangan lahan disekitar rumah langsung dilakukan bersama-sama dengan masyarakat dikelurahan tersebut dengan target adalah masyarakat yang ada di RT 03. Kegiatan edukasi untuk kesadaran pentingnya pencegahan penyebaran Covid-19 dilakukan dengan penyuluhan kerumah-rumah dengan membagikan brosur dan juga masker bagi masyarakat RT 03.

Setelah kegiatan berakhir dilakukan evaluasi dan monitoring agar mengetahui sejauh mana keberhasilan dari kegiatan yang sudah dilakukan.

\section{Hasil dan Pembahasan}

Pelatihan dan edukasi yang telah diberikan kepada masyarakat di kelurahan sabaru sangat signifikan berpengaruh bagi kesadaran masyarakat pentingnya pencegahan penyebaran Covid-19 dan kesadaran memanfaatkan lahan kosong disekitar rumah sebagai ketahanan pangan keluarga. Pendemi Covid-19 sampai saat ini masih terus berlangsung di berbagai belahan dunia dengan berbagai variasi tingkat kejadian yang berbeda, di negara Indonesia kasus pendemi Covid-19 menunjukan kasus yang berbeda antar daerah, kabupaten, dan provinsi dan cenderung terjadi peningkatan untuk pulau Kalimantan. Dari berbagai protokol pencegahan Covid-19 yang di terapkan oleh pemerintah daerah Provinsi dan Kabupaten/Kota di Kalimantan Tengah, berdasarkan data sekunder yang bersumber dari Satuan Tugas Covid19 Kalimantan Tengah nampaknya penyebaran virus corona ini masih belum akan berakhir dalam waktu dekat. Beberapa kegiatan yang dilakukan dalam rangka pencegahan penyebaran Covid-19 adalah dengan pembagian masker dan melakukan penyemprotan desinfektan kerumah penduduk, selain itu disosialisasikan bahaya dari Covid-19 dan mulai sekarang juga secara bertahap dilakukan vaksin terhadap masyarakat . 


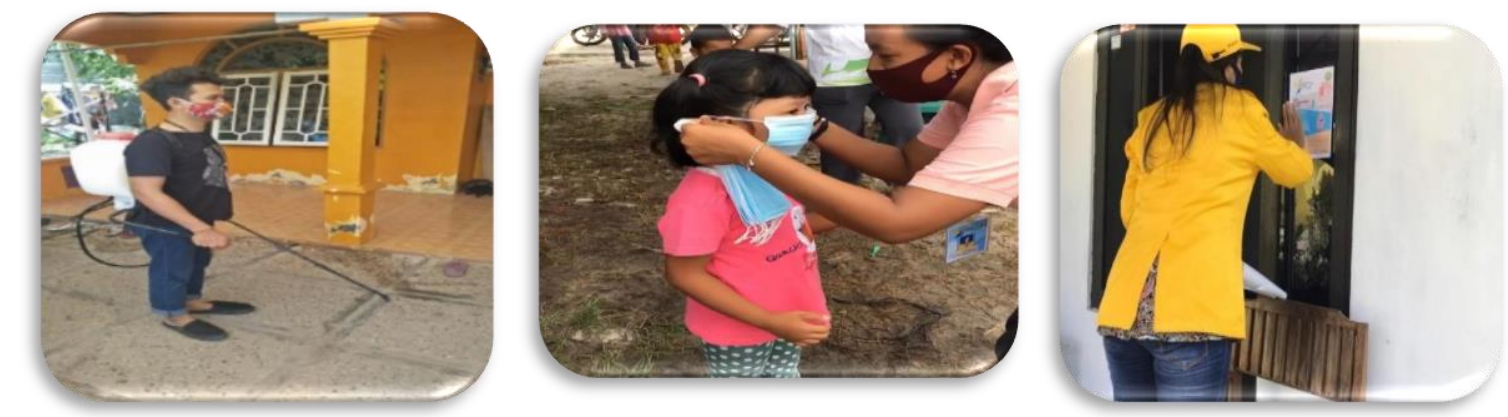

Gambar 2. Dokumentasi Kegiatan pengabdian

Sampai saat ini, belum ada vaksin yang betul-betul tepat untuk mencegah infeksi virus Corona atau Covid-19 karena sampai saat ini masih ada beberapa vaksin yang masih diuji cobakan untuk menghentikan penyebaran Covid-19 ini yang disebarkan oleh virus. Oleh sebab itu, cara pencegahan yang terbaik adalah dengan :

- Menerapkan physical distancing, yaitu menjaga jarak minimal 1 meter dari orang lain, dan jangan dulu ke luar rumah kecuali ada keperluan mendesak.

- Gunakan masker saat beraktivitas di tempat umum atau keramaian.

- $\quad$ Rutin mencuci tangan dengan air dan sabun atau hand sanitizer yang mengandung alkohol minimal $60 \%$, terutama setelah beraktivitas di luar rumah atau di tempat umum.

- Jangan menyentuh mata, mulut, dan hidung sebelum mencuci tangan.

- Tingkatkan daya tahan tubuh dengan pola hidup sehat.

- Hindari kontak dengan penderita Covid-19, orang yang dicurigai positif terinfeksi virus Corona, atau orang yang sedang sakit demam, batuk, atau pilek.

- Tutup mulut dan hidung dengan tisu saat batuk atau bersin, kemudian buang tisu ke tempat sampah

- Jaga kebersihan benda yang sering disentuh dan kebersihan lingkungan, termasuk kebersihan rumah.

Untuk orang yang diduga terpapar Covid-19 atau termasuk kategori orang dalam pengawasan (ODP) maupun pasien dalam pengawasan (PDP), ada beberapa langkah yang bisa dilakukan agar virus Corona tidak menular ke orang lain, yaitu:

- Lakukan isolasi mandiri dengan cara tinggal terpisah dari orang lain untuk sementara waktu. Bila tidak memungkinkan, gunakan kamar tidur dan kamar mandi yang berbeda dengan yang digunakan orang lain.

- Jangan keluar rumah, kecuali untuk mendapatkan pengobatan.

- $\quad$ Bila ingin ke rumah sakit saat gejala bertambah berat, sebaiknya hubungi dulu pihak rumah sakit untuk menjemput.

- $\quad$ Larang dan cegah orang lain untuk mengunjungi atau menjenguk Anda sampai Anda benar-benar sembuh.

- $\quad$ Sebisa mungkin jangan melakukan pertemuan dengan orang yang sedang sakit.

- Hindari berbagi penggunaan alat makan dan minum, alat mandi, serta perlengkapan tidur dengan orang lain.

- $\quad$ Pakai masker dan sarung tangan bila sedang berada di tempat umum atau sedang bersama orang lain

- $\quad$ Gunakan tisu untuk menutup mulut dan hidung bila batuk atau bersin, lalu segera buang tisu ke tempat sampah.

Kegiatan Pengabdian masyarakat yang telah dilakukan melihat kondisi nyata yang ada 
dilokasi adalah kurang nya kesadaran masyarakat dalam menggunakan masker dan melakukan cuci tangan dikarenakan minimnya tempat cuci tangan dilikungan perumahan setempat dan juga kurangnya penerapan dalam menjaga jarak. Kegiatan Berikutnya adalah dengan pengembangan ketahanan pangan masyarakat yang memanfaatkan lahan masyarakat yang tidak digunakan dan lokasi pada lahan yang tidak jauh dari perumahan warga dan juga pada halaman rumah warga yang selama ini tidak dimanfaatkan. Berikut adalah dokumentasi kegiatan pendampingan yang dilaksanakan untuk memberikan pelatihan kepada masyarakat memanfaatkan lahan pekarangan untuk ditanami sayur mayur yang bermanfaat untuk ketahanan pangan keluarga.
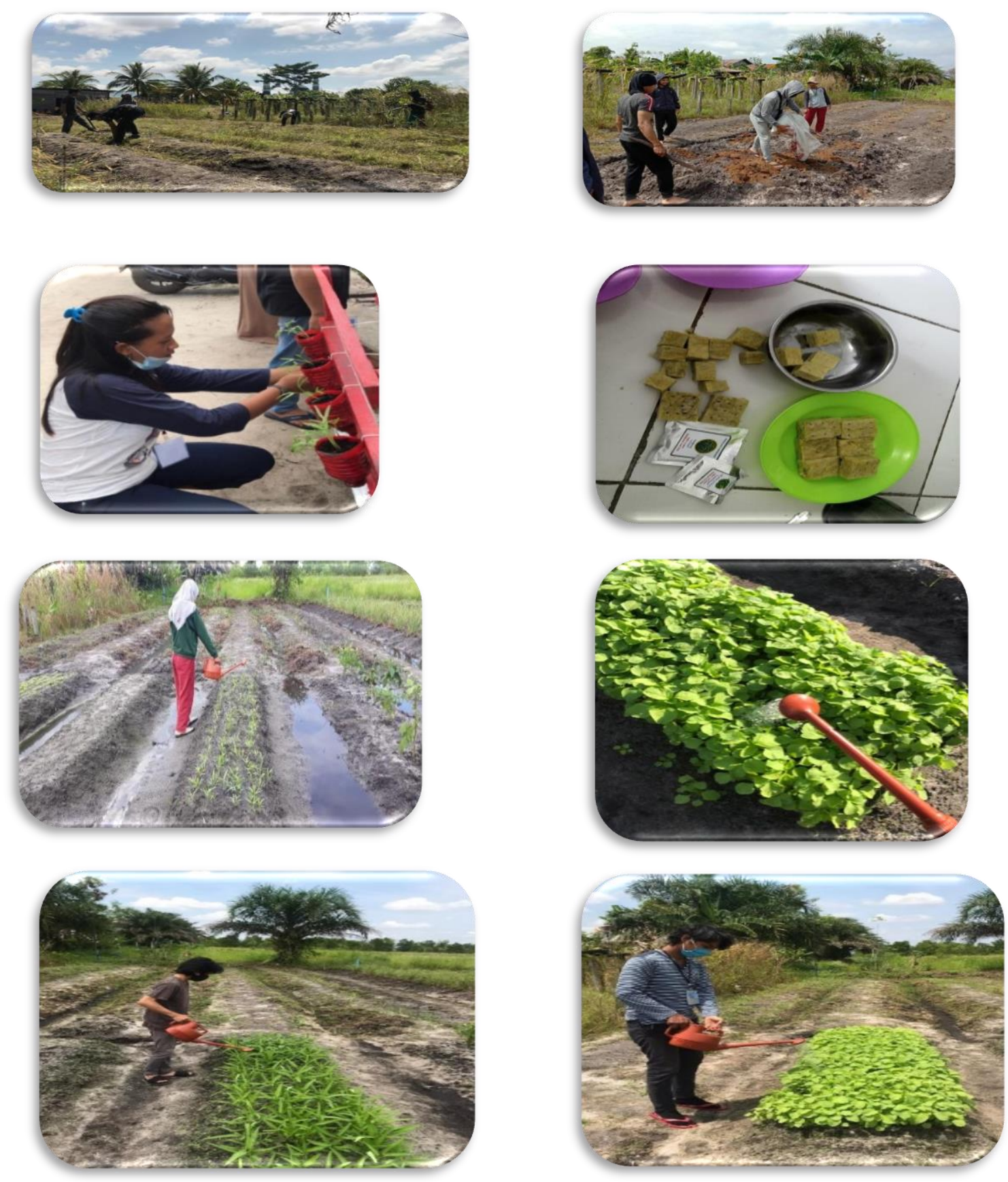

Gambar 3. Kegiatan Pemanfaatan Lahan pekarangan 
Dalam rangka mewujudkan ketahanan pangan, sektor pertanian merupakan sektor yang sangat penting karena sektor ini menjadi penyedia pangan utama, apabila dicermati konsep ketahanan pangan tersebut, ketahanan pangan tidak hanya menyangkut aspek, jumlah, namun juga menyangkut aspek mutu, keamanan, dan gizi pangan (Rachman 2002; Sumastuti dan Efriani, 2010) lebih-lebih untuk negara yang sedang berkembang pangan merupakan faktor utama dalam peningkatan SDM (Suradi, 2015). Ketahanan pangan dapat diartikan sebagai keadaan semua manusia memiliki akses baik secara fisik, social, dan ekonomi untuk memperoleh pangan yang cukup, aman, dan bergizi sesuai kebutuhan dan preferensi untuk hidup aktif dan sehat, karena memiliki peran ganda yaitu sebagai salah satu sasaran utama pembangunan dan salah satu instrumen utama pembangunan ekonomi. Fungsi ketahanan pangan sebagai prasyarat untuk terjaminnya akses pangan determinan utama dari inovasi ilmu pengetahuan, teknologi dan tenaga kerja produktif serta fungsi ketahanan pangan sebagai salah satu cerminan lingkungan perekonomian yang stabil dan kondusif bagi pembangunan. Setiap negara senantiasa berusaha membangun sistem ketahanan pangan yang mantap, oleh sebab itu sangat rasional dan wajar kalau Indonesia menjadikan program pemantapan ketahanan pangan nasional sebagai prioritas utama pembangunannya. Ketahanan pangan yang merupakan terjemahan dari food security mencakup banyak aspek dan luas sehingga setiap orang mencoba menterjemahkan sesuai dengan tujuan dan ketersediaan data. Dalam Undang-Undang Nomor 18 tahun 2012 tentang Pangan, ketahanan pangan nasional diartikan sebagai kemampuan suatu bangsa untuk menjamin seluruh penduduknya untuk memperoleh pangan yang cukup, baik jumlah maupun mutunya, aman, beragam, bergizi, merata dan terjangkau serta tidak bertentangan dengan agama, keyakinan dan budaya masyarakat, untuk dapat hidup sehat, aktif dan produktif secara berkelanjutan. Pengertian mengenai ketahanan pangan tersebut mencakup aspek makro dan mikro, Pada aspek makro, ketahanan pangan pada tingkat nasional diartikan sebagai kemampuan suatu bangsa untuk menjamin seluruh penduduknya memperoleh pangan yang cukup, mutu yang layak, dan aman yang didasarkan pada optimalisasi pemanfaatan yang berbasis pada keragaman sumberdaya lokal. Sedangkan pada aspek mikro, ketahanan pangan diartikan sebagai terpenuhinya kebutuhan pangan setiap rumah tangga dan individu untuk menjalani hidup yang sehat dan aktif. Karena produksi pangan nasional sebagian besar dilakukan petani dengan skala usaha kecil yang merupakan masyarakat miskin di pedesaan, maka ketahanan pangan erat kaitannya dengan penguatan ekonomi pedesaan dan pengentasan kemiskinan (Dewan Ketahanan Pangan, 2006). Selanjutnya juga diungkapkan bahwa defisini ketahanan pangan berubah dari satu periode waktu ke periode waktu lainnya.

Bahtiar (2020) Dalam mewujudkan ketahanan pangan di Indonesia, masih terdapat beberapa permasalahan di sektor pertanian yang harus dihadapi dan diatasi, seperti : kebijakan pengelolaan dan pengembangan komoditas pangan, termasuk teknologinya yang hanya terfokus pada beras; teknologi pasca panen belum banyak diterapkan dengan baik; belum memadainya prasarana dan sarana transportasi; dan ketidakstabilan harga dan rendahnya efisiensi sistem pemasaran hasil-hasil pangan. Kenaikan harga pangan bagi keluarga yang tidak bekerja atau yang bekerja tetapi penghasilannya tidak cukup, dapat mengancam kebutuhan gizinya yang berarti ketahanan pangan keluarganya terancam. Sebaliknya, persediaan cukup, harga stabil tetapi banyak penduduk tanpa kerja dan tanpa pendapatan, berarti tanpa daya beli, juga menyebabkan persediaan pangan itu tidak efektif. Karena itu pembangunan Sumberdaya Manusia (SDM) akan mengatur keseimbangan dan keserasian antara kebijaksanaan sistem pangan (produksi, distribusi, pemasaran, dan konsumsi) dan kebijaksanaan di bidang sosial seperti penanggulangan kemiskinan, pendidikan, kesehatan, gizi dan lain-lain. 
Kelurahan sabaru terdapat masyarakat yang memiliki rasa kepedulian yang tinggi terhadap lingkungan sekitar, sehingga kegiatan pengabdian kepada masyarakat yang dilakukan dapat dengan mudah diterima masyarakat dan mereka mau menerapkannya. Pencegahan penularan Covid-19 dan peningkatan ketahanan pangan merupakan kegiatan yang langsung dapat dirasakan keluarga manfaatnya.

\section{Simpulan}

Lahan disekitar rumah dapat dimanfaatkan untuk bertanam sayuran dalam rangka ketahanan pangan bagi masyarakat sehingga lahan kosong tidak ada yang terbengkalai lagi tanpa dimanfaatkan. Masyarakat menyadari pentingnya pencegahan penularan Covid-19 dengan mentaati protokol kesehatan yaitu : menggunakan masker, cuci tangan dan menjaga jarak dengan tidak berkerumun.

\section{Daftar Pustaka}

Aisyah Siti Iseu. (2020) Ketahanan Pangan Keluarga Di Masa Pandemi Covid-19 Jurnal

Kesehatan komunitas Indonesia Vol 16 no 2; 179-189.

Apriati Yuli dan Azkia Laila (2020). Pelatihan Pembuatan Hand Sanitizer Untuk Anak Sekolah Dasar Sebagai Edukasi Pencegahan Dini Covid-19 Di Lingkungan Rt.15 Kompleks

Perdana Mandiri Kelurahan Sungai Andai, Banjarmasin Utara. Padaringan Jurnal Pendidikan Sosiologi Antropologi Volume 2 No.3 : 294-302

Badan Ketahanan Pangan. (2005). Kebijakan Umum Ketahanan Pangan

Bachtiar., 2020., Tantangan dan Peran Bulog di Era Industri 4.0. Pangan, Vol. 29 No.1:71 -86

Dewan Ketahanan Pangan. (2006). Kebijakan Umum Ketahanan Pangan 2006-2009. Jakarta: Dewan Ketahanan Pangan

Fadli, a. (2020). Mengenal covid-19 dan cegah penyebarannya dengan "peduli lindungi" aplikasi berbasis android. Artikel Pengabdian Kepada Masyarakat Jurusan Teknik Elektro Universitas jendral soedirman.

Partomo, T.S., dan Soejoedono, A.R. (2004). Ekonomi Skala Kecil/Menengah dan Koperasi. Jakarta : Ghalia Indonesia

Purwaningsih, Y. (2008). Ketahanan Pangan : Situasi, Permasalahan, Kebijakan, dan Pemberdayaan Masyarakat. Jurnal Ekonomi Pembangunan, 9 (1) : 1 - 27

Rachman, H.P.S., dan Ariani, M. (2002). Ketahanan Pangan : Konsep, Pengukuran dan Strategi. Pusat Penelitian dan Pengembangan Sosial Ekonomi Pertanian Bogor, 20 (1) : 12-24

Suradi. 2015. Kebutuhan Pangan bagi Rumah Tangga Miskin. Sosio Informa Vol. 01, No. 1, Januari-April, Tahun 2015: 1-12.

Sumastuti, Efriyani. 2010. Jiwa Entrepreneurship untuk Mewujudkan Ketahanan Pangan. Jejak Jurnal Ekonomi dan Kebijakan. Vol 3 Nomor 1, Maret 